\title{
CARBON ISOTOPES IN WOOD COMBUSTION/PYROLYSIS PRODUCTS: EXPERIMENTAL AND MOLECULAR SIMULATION APPROACHES
}

\author{
HELENA HERCMAN, MAREK SZCZERBA, PAWEL ZAWIDZKI and AGATA TROJAN \\ Institute of Geological Sciences, Polish Academy of Sciences, ul. Twarda 51/55, PL-00-818 Warszawa, Poland
}

Received 5 December 2018

Accepted 2 April 2019

\begin{abstract}
A series of laboratory experiments was performed to determine the carbon stable isotopic composition of different combustion/pyrolysis $(\mathrm{B} / \mathrm{P})$ products. Variation in the $\delta^{13} \mathrm{C}$ values of the products was observed, up to $4 \%$. The differences in the carbon isotopic compositions of the $\mathrm{B} / \mathrm{P}$ products were dependent on temperature, time and wood type. Comparison of the results for fresh and fossil oak wood suggested that the $\delta^{13} \mathrm{C}$ differences were the effect of selective decomposition of some wood components during the fossilization process. The temperature dependence of the carbon isotopic composition was linked to variation in the carbon isotopic composition of the main wood components, which each had different levels of thermal stability. Isotopes exchange reactions in between different products can be also considered as possible source of variation of $\delta^{13} \mathrm{C}$ on temperature. Both these hypotheses were supported by molecular simulations of cellulose and lignin B/P.

The results confirm that $\mathrm{B} / \mathrm{P}$ should be treated as a continuous process, where the results depend on the degree of process development. Natural burning processes are dynamic and burning conditions change rapidly and it is necessary to take care when using combustion products as a paleoenvironmental proxy or as an isotopic characteristic for the identification of source material.
\end{abstract}

Keywords: carbon isotopes, combustion/pyrolysis, wood burning experiment, molecular simulations.

\section{INTRODUCTION}

The products of organic matter $(\mathrm{OM})$ combustion or pyrolysis $(\mathrm{B} / \mathrm{P})$, have been commonly applied to environmental and paleoenvironmental characterization and reconstruction or as a basis for the chronology of deposits in sedimentology and archaeology. Wood B/P is thermal decomposition that evolves flammable gases being ignited in the presence of $\mathrm{O}_{2}$ when the temperature exceeds the temperature of ignition. The final burning products, under ideal conditions, are $\mathrm{CO}_{2}$ and $\mathrm{H}_{2} \mathrm{O}$. In practice, $\mathrm{B} / \mathrm{P}$ never proceeds under ideal conditions and, as a result, different products are formed. Material produced from

Corresponding author: H. Hercman e-mail: hhercman@twarda.pan.pl
$\mathrm{B} / \mathrm{P}$ varies and is described by different names: charcoal, soot, black carbon, elemental carbon, biochar and pyrogenic carbon (Bird, 2006; Preston and Schmidt, 2006; Bird and Ascough, 2012 and Pawlyta and Hercman, 2016). This reflects the complexity of its composition and structure, as well as its importance in a range of scientific areas. These $\mathrm{B} / \mathrm{P}$ products differ not only in terminology but also in the methodology of analysis and interpretation of the results.

Combustion and pyrolysis of OM produces different types of carbon rich material. During the $\mathrm{B} / \mathrm{P}$ processes, the relative content of carbon increases and is accompanied by a decrease in $\mathrm{O}$ and $\mathrm{H}$, resulting from organic compound degradation. Because of increasing carbon content and structural changes, chemically stable aromatic rings are formed. The products final structure is $\mathrm{B} / \mathrm{P}$ temperature dependent. At higher temperatures, microcrystalline domains may be formed and chemical 
stability is greater, making $\mathrm{B} / \mathrm{P}$ products resistant to postdepositional alteration (Goldberg, 1985; Vane and Abbott, 1999; Masiello, 2004; Czimczik et al., 2005; Preston and Schmidt, 2006; Eckmeier et al., 2007 and Bird and Ascough, 2012).

The resistant black residue that remains after $\mathrm{B} / \mathrm{P}$ of $\mathrm{OM}$ is responsible for its common occurrence in a wide range of materials and environments. The occurrence of the products has been studied in very old sediments (Cressler, 2001), soils (Schmidt et al., 2002; Brodowski et al., 2005 and Lehmann et al., 2008), in the atmosphere (Cachier et al., 1989) as well as in terrestrial and marine sediments of different age (Bird and Cali, 1998; Masiello and Druffel, 1998; Manino and Harvey, 2004; Dittmar and Koch, 2006; Haberstroh et al., 2006 and Dittmar and Paeng, 2009) or in caves (Chang et al., 2008; Gradziński et al., 2003, 2007 and Joeng et al., 2003).

The carbon isotopic composition of $\mathrm{B} / \mathrm{P}$ products is widely used as a proxy in paleoclimatic, paleoecological, archaeological and biological studies or as an isotopic fingerprint (Bird and Cali, 1998; Cressler , 2001; Hall et al, 2008; Schmidt et al., 2002; Joeng et al., 2003; Czimczik et al., 2005; Ferio et al., 2006; Chang et al., 2008 and Song et al, 2012). Such a wide application caused intensive studies of $\mathrm{B} / \mathrm{P}$ processes and carbon isotopic fractionation. The studies usually resulted from interests and needs of researchers and concerned only on selected products of combustion. Most current research is related to charcoal.

The importance of this information has resulted in extensive methodological and experimental studies of the relation between $\mathrm{B} / \mathrm{P}$ conditions and the isotopic composition of the $\mathrm{B} / \mathrm{P}$ products. Most studies focus on the isotopic composition of charcoal, with respect to the $\mathrm{B} / \mathrm{P}$ conditions (temperature, time, atmosphere; see Bird and Ascough, 2012). In Bird and Ascough (2012), the results of previous work were not only reviewed but a detailed discussion of factors affecting the results was provided, including the choice of material for testing, sample preparation, experimental methodology and analysis methodology.

The black residue that remains after wood combustion is a common material for archaeological and geological investigations. Most published results from these analyses concern carbonaceous microstructural studies, radiocarbon analyses and stable isotopic analyses in aerosols and clastic deposits (Currie et al., 1997; Masiello et al., 2002 and Brodowski et al., 2005). The primary reason for these studies is increasing interest in nanoparticles and their impact on the environments and humans (see review and references there: Nowack and Bucheli, 2007). Investigations of the accumulated wood combustion products in sediments give the chance to determine their provenance: human activity and natural phenomena (like forest or meadow fires). In archaeological and geological investigations it is also very important to distinguish the products from different sources that can be commonly found in the modern environment (e.g. wood burning at the fires, fossil fuel combustion in the engines, industry).

Several studies have examined carbonaceous material from caves. These studies have mostly been for archaeological purposes or to provide information about $\mathrm{B} / \mathrm{P}$ product precursor (Petranek and Pouba, 1951; Bennington et al., 1962; Watson, 1966; Hill, 1982; Steelman et al., 2002; Gradziński et al., 2002, 2003, 2007; Chang et al., 2008 and Pawlyta and Hercman, 2016).

Products of the complete wood combustion are mostly gaseous, however in the case of incomplete burning, these can form well visible black layer or can be dispersed in the sediment. In the second case, identification of burning wood product is more difficult. One of the common products of incomplete combustion are soot aggregates, which have characteristic structure and can be easily identified even in extremely low concentrations using the transmission electron microscopy (TEM) or scanning electron microscopy (SEM) techniques after relatively simple chemical separation (Pósfai and Molnár, 2000 and Pawlyta and Hercman, 2016).

In our studies of lake and cave deposits we often found traces of combustion products dispersed in the sediments or inside of carbonate speleothems. Separated soot aggregates allow identification of the type of combusted material (Joeng et al, 2003; Chang et al., 2008 and Pawlyta and Hercman, 2016). In our research, we set question whether the carbon isotopic composition in the soot aggregates corresponds to the carbon isotopic composition of the combusted material (e.g. wood) and thus it can be used, for example, as a paleo environmental proxy. In order to get an answer to the question asked, several experiments have been performed and isotopic composition of solid, liquid, condensed volatile and gaseous products of combustion were investigated.

\section{MATERIAL}

Three types of modern wood were selected: pine ( $P i-$ nus sp.), oak (Oak sp.) and beech (Beech sp.). In addition, a sample of fossil oak was obtained from the Krakow Dendrochronological Laboratory. The basic data of the collected samples (locality, cutting time, growth period) together with measured carbon isotopic composition are presented in Table 1. For the beech and oak trunks, samples with 9 yr of growth rings, covering years 20012009 , were selected. The pine trunk was smaller than the beech and oak trunks, so a $13 \mathrm{yr}$ sample was selected, covering years 2001-2013. The samples, around $300 \mathrm{~g}$ of modern wood and $200 \mathrm{~g}$ of fossil oak, were chipped and homogenized. Part of the material (around $200 \mathrm{~g}$ ) was used in experiments with a burning chamber, and the remains were pulverized using an agate mill. The obtained powder was then used in furnace experiments. The carbon isotopic composition of the wood samples was estimated as a mean value using a series of measurements (either 10 for fossil oak or 30 for modern wood). The age 
Table 1. Basic data of wood samples.

\begin{tabular}{|c|c|c|c|c|c|c|}
\hline Wood & Sample & Locality & Cut date & Coordinates & $\begin{array}{l}\text { Growth perioda }^{a} \\
\text { (A.D.) }\end{array}$ & $\begin{array}{cc}\mathrm{N}^{\mathrm{b}} & \begin{array}{c}\text { Mean } \delta^{13} \mathrm{C} \\
(\% \mathrm{~V} \text { PDB }\end{array} \\
\end{array}$ \\
\hline Pine & S2 & Siedlce & 2014, March & $52^{\circ} 10^{\prime} 00^{\prime \prime} \mathrm{N} 22^{\circ} 16^{\prime} 30^{\prime \prime} \mathrm{E}$ & $2013-2001$ & $30-26.5 \pm 0.2$ \\
\hline Oak & D1 & Ojców & 2014, October & $50^{\circ} 12^{\prime} 24^{\prime \prime N} 19^{\circ} 49^{\prime} 45^{\prime \prime E}$ & $2009-2001$ & $30-27.4 \pm 0.3$ \\
\hline Beech & B1 & Błonie & 2014, November & $52^{\circ} 11^{\prime} 48^{\prime \prime N} 20^{\circ} 37^{\prime} 01^{\prime \prime} \mathrm{E}$ & 2009-2001 & $30-24.7 \pm 0.2$ \\
\hline \multicolumn{7}{|c|}{ Fossil oak } \\
\hline Wood & Sample & Locality & & $\begin{array}{c}\text { Radiocarbon age } \\
\text { (yrs) }\end{array}$ & $\begin{array}{c}\text { Calibrated radiocarbon age }^{\mathrm{c}} \\
\text { (cal BP yrs) }\end{array}$ & $\begin{array}{c}\text { Mean } \delta^{13} \mathrm{C} \\
(\%)\end{array}$ \\
\hline Fossil oak & $C D$ & Krakow (lab.) & Archivized sample & $\begin{array}{c}\text { Poz-79538 } \\
1275 \pm 30 \mathrm{BP}\end{array}$ & $\begin{array}{l}1265-1184 \\
1289-1150 \\
\end{array}$ & $10-25.8 \pm 0.2$ \\
\hline
\end{tabular}

${ }^{a}$ Timespan covered by sample analyzed;

${ }^{b}$ number of stable isotope analyses;

c radiocarbon age calibration using OxCal 4.2.4 (Bronk Ramsey, 2009) and IntCal13 atmospheric curve (Reimer et al., 2013).

of the fossil oak was estimated based on radiocarbon analysis performed at the Poznań Radiocarbon Laboratory.

\section{METHODS}

\section{Wood burning experiments}

Two sets of wood burning/pyrolysis experiments were performed using burning chamber and furnace. Several types of samples for carbon stable isotope analyses were collected depending on experiment type. In the further part of the work we will use the terms: (1) "charcoal" for charred wood - black residuum collected from burning plate or from sample tube; (2) "ash" for gray powder collected from ash collector; (3) "acid" for transparent liquid sample with $\mathrm{pH} \sim 1$ ("pyroligneous acid" consisting mainly of acetic acid and methanol); (4) "bio-oils" for yellow-brown colour oleic liquid and (5) soot aggregates for separated soot from volatiles condensed at collecting plate.

The first set of experiments involved the simulation of a fireplace in a burning chamber. The wood sample (80$100 \mathrm{~g}$ ) was located at the burning plate and an ash collector was located below the burning plate. The volatile burning products, e.g. soot aggregates, were collected as condensed products on the quartz-glass plate located $15 \mathrm{~cm}$ above the fireplace. Two thermocouples allowed control of the burning temperature and the collecting plate temperature. Burning temperature was around 400 $500^{\circ} \mathrm{C}$. The maximum temperature in the upper part of the flame was $800^{\circ} \mathrm{C}$. At the top of the burning chamber a tube for gas product collection was installed. The gas tube was connected through the particle trap and water vapor trap directly to the Picarro G2201-i Analyzer or via the membrane pump to a sampling bag. After each experiment, several burning products were collected for further analysis: "charcoal", "ash" and volatile products condensed onto the collecting plates.

The next set of experiments was carried out in a furnace. Powdered wood sample (1-2 g) was put in a quartz tube between two quartz wool plugs, which was then placed in the heating chamber pre-heated to a predetermined temperature. The temperature was increased gradually in $50^{\circ} \mathrm{C}$ intervals in the $200-600^{\circ} \mathrm{C}$ range. At each temperature increment, the sample was kept for $45 \mathrm{~min}$. A thermocouple was put inside the sample to allow temperature control. Experiments were performed under an atmosphere of $\mathrm{N}_{2}$ or synthetic air $\left(21 \% \mathrm{O}_{2}\right.$ and $79 \% \mathrm{~N}_{2}$; $\left.\mathrm{H}_{2} \mathrm{O}<3 \mathrm{ppm}, \mathrm{CO}<0,1 \mathrm{ppm}, \mathrm{CO}_{2}<0,5 \mathrm{ppm}, \mathrm{H}_{2}<1 \mathrm{ppm}\right)$. At the exit of the sample tube, a water cooler was mounted to facilitate condensation of the volatile products released during the experiment. For further analysis, the "charcoal" and volatile components, condensed at the cooled exit of the sample tube ("acids" and "bio-oils"), were collected.

\section{Burning product collection and pre-treatment}

Wood, "charcoal", "acids", "bio-oils" and "ash" were analysed without any pre-treatment. Volatile products condensed at the collecting plate of burning chamber were mixtures of different $\mathrm{B} / \mathrm{P}$ products, including soot, char and tar. To obtain information about the soot aggregates carbon isotopic composition, several purification steps were applied. Volatile products collected at the plate were divided into three parts in order to check the possible impact of the purification procedure on the isotopic composition. First part was analysed without pretreatment; second one was treated with $2 \% \mathrm{HCl}(3$ times, each $24 \mathrm{~h}$ in room temperature with washing between the acid steps); and third part was treated with $2 \% \mathrm{HCl}$ (similarly as in the second step) and $40 \%$ HF for $1 \mathrm{~h}$. At the end of the chemical procedure, the samples were repeatedly $(c a .10 \times)$ washed with deionised water. This pretreatment scheme is typical for the purification of soot aggregates (Pawlyta and Hercman, 2016).

\section{Carbon stable isotope measurements}

Carbon stable isotopes composition analysis was performed at the Stable Isotope Laboratory of the Institute of Geological Sciences of the Polish Academy of Sciences in Warsaw. Stable isotopic composition of carbon for 
solid and liquid samples (wood, charred wood, soot aggregates, ash and oil) was determined using a Thermo Flash EA 1112 HT elemental analyser connected to a Thermo Delta V Advantage Isotope Ratio Mass Spectrometer in continuous flow mode. Samples $(c a .250 \mu \mathrm{g})$ were wrapped in $\mathrm{Sn}$ capsules and combusted at $1020^{\circ} \mathrm{C}$. The carbon isotope ratio was calculated using a calibration curve based on several international standards (USGS 40, USGS 41, IAEA 600, IAEA C7 and NBS 22). To control the measurement conditions, an laboratory standard (Nicotinamide Standard) was measured after each batch of 5 samples. The number of samples taken for analysis of specific $\mathrm{B} / \mathrm{P}$ products depended on the amount of material available and ranged from 3 to 9 . Reported uncertainties represent $95 \%$ confidence interval calculated basing on laboratory standard measurements results from the period of research conduction.

The carbon isotopic composition of $\mathrm{CO}_{2}$ was measured by a Picarro G2201-i Analyzer using a cavity ringdown spectroscopy (CRDS) method. At the experiment time, $\mathrm{CO}_{2}$ was continuously pumped at $c a .50 \mathrm{ml} / \mathrm{min}$ and collected in sampling bag. Collected $\mathrm{CO}_{2}$ was mixed with artificial air in another sampling bags for carbon concentrations close to $2000-3000 \mathrm{ppm}$, which is optimal the for G2201-I Analyzer (recommended by producer $\mathrm{CO}_{2}$ operational range is $100-4000 \mathrm{ppm}$ ). Prepared gas mixture was measured by Picarro G2201-i Analyzer. Reported results represent average value from 10-20 minute measurement (carbon isotopic composition is measured every $3 \mathrm{~s}$ ).

Isotope ratios are reported as dispersion from the standard ( $\delta$ value) and expressed in \%o relative to V-PDB standard.

For the description of carbon isotopic composition, we define the "variation factor" $(\Delta \mathrm{C})$ as the difference between average of measured $\delta^{13} \mathrm{C}$ values in the $\mathrm{B} / \mathrm{P}$ product and the average of the bulk wood sample (listed in Table 1):

$\Delta \mathrm{C}=\delta^{13} \mathrm{C}_{\text {(average for B/P product) }}-\delta^{13} \mathrm{C}_{\text {(average for wood) }}[\%$ ]

According to this definition, positive values of $\Delta \mathrm{C}$ indicate enrichment in ${ }^{13} \mathrm{C}$ in the products relatively to the wood. Negative values of $\Delta \mathrm{C}$ indicate depletion of ${ }^{13} \mathrm{C}$ in the product relatively to the wood. Due to the small number of samples, $95 \%$ confidence intervals of $\Delta \mathrm{C}$ were estimated using Monte Carlo simulation method.

\section{Molecular simulations}

In order to explain relationships between carbon isotopes in the solid, liquid and gaseous combustion products, two series of molecular simulations were performed.

In the first one, models of two the most abundant components of wood, were tested: cellulose and lignin. Cellulose structure was built of 9 glucose monomers. Lignin model containing $\mathrm{C}_{160} \mathrm{H}_{180} \mathrm{O}_{58}$ was provided by courtesy of Tingting Zhang (Zhang et al., 2016). Reaxff force field optimized for $\mathrm{C} / \mathrm{H} / \mathrm{O}$ combustion (Chenoweth et al., 2008) was used in LAMMPS computer simulation program (Plimpton, 1995). Timestep was set at $0.25 \mathrm{ps,}$ cutoff at $10.0 \AA$ and temperature was increasing continuously $1^{\circ} \mathrm{C} /$ ps from $27^{\circ} \mathrm{C}$ up to $2227^{\circ} \mathrm{C}$ in the NVT ensemble. Simulations for single molecules and with additional oxygen in pressure of ca 10 atm. were additionally performed. Based on the results of simulations, evolution with temperature of pyrolysate masses containing certain number of carbon atoms were calculated. Analysis of the simulation frames was performed recursively for all atoms - atoms belong to chain with certain number of carbon atoms if it was in distance below $1.8 \AA$ to any atom building the molecule $(\mathrm{C}, \mathrm{O}, \mathrm{H})$. In order to improve statistics, six series of simulations were performed in the same conditions but with slightly modified starting structure.

In the second set of simulations, an isotope exchange reactions between pyrene (a model of residuum) and different gaseous and liquid products were tested:

$$
\begin{aligned}
& { }^{12} \mathrm{C}_{16} \mathrm{H}_{10}+16{ }^{13} \mathrm{CO}_{2} \leftrightarrow{ }^{13} \mathrm{C}_{16} \mathrm{H}_{10}+16{ }^{12} \mathrm{CO}_{2} \\
& \left(\mathrm{CO}_{2}\right) \\
& { }^{12} \mathrm{C}_{16} \mathrm{H}_{10}+16{ }^{13} \mathrm{CH}_{2} \mathrm{O} \leftrightarrow{ }^{13} \mathrm{C}_{16} \mathrm{H}_{10}+16{ }^{12} \mathrm{CH}_{2} \mathrm{O} \\
& \text { (formaldehyde) } \\
& { }^{12} \mathrm{C}_{16} \mathrm{H}_{10}+8 \mathrm{HO}^{13} \mathrm{CH}_{2}{ }^{13} \mathrm{CHO} \leftrightarrow{ }^{13} \mathrm{C}_{10} \mathrm{H}_{10}+8 \mathrm{HO}^{12} \mathrm{CH}_{2}{ }^{12} \mathrm{CHO} \\
& \text { (glycoaldehyde) } \\
& 3{ }^{12} \mathrm{C}_{16} \mathrm{H}_{10}+16\left({ }^{13} \mathrm{CH}_{3}\right)_{2}{ }^{13} \mathrm{CO} \leftrightarrow 3{ }^{13} \mathrm{C}_{16} \mathrm{H}_{10}+16\left({ }^{12} \mathrm{CH}_{3}\right)_{2}{ }^{12} \mathrm{CO} \\
& \text { (acetone) }
\end{aligned}
$$

The aim was to calculate $\Delta$ energy, $\Delta$ enthalpy and $\Delta$ Gibbs free energy of reactions along with zero-point energy (ZPE) and thermal corrections at two significantly different temperatures of $27^{\circ} \mathrm{C}(300 \mathrm{~K})$ and $427^{\circ} \mathrm{C}$ $(700 \mathrm{~K})$. After optimization of all the structures, vibration frequencies were computed. Thermal corrections were calculated based on translational, rotational and vibrational contributions (Ochterski, 2000). All the calculations were performed using Gaussian 03 program (Frisch et al., 2004) with Density Functional Theory (DFT) at the B3LYP/DGDZVP level of theory. All the thermodynamic parameters were also provided by Gaussian 03 program.

\section{RESULTS}

\section{Burning/pyrolysis experiments}

\section{Estimating the experiments temperature range}

At the beginning, the temperature range of the experiments had to be determined. The furnace experiments with pine wood were carried out in a $\mathrm{N}_{2}$ and synthetic air (free of $\mathrm{CO}_{2}$ ) atmosphere. The furnace temperature was increased gradually in $50^{\circ} \mathrm{C}$ intervals (Fig. 1B), and continuous measurements of the $\mathrm{CO}_{2}$ concentration were performed (Fig. 1A). The only source of $\mathrm{CO}_{2}$ was the reaction of wood $\mathrm{B} / \mathrm{P}$, meaning the appearance of $\mathrm{CO}_{2}$ was an indicator of the wood decomposition, with $\mathrm{CO}_{2}$ 


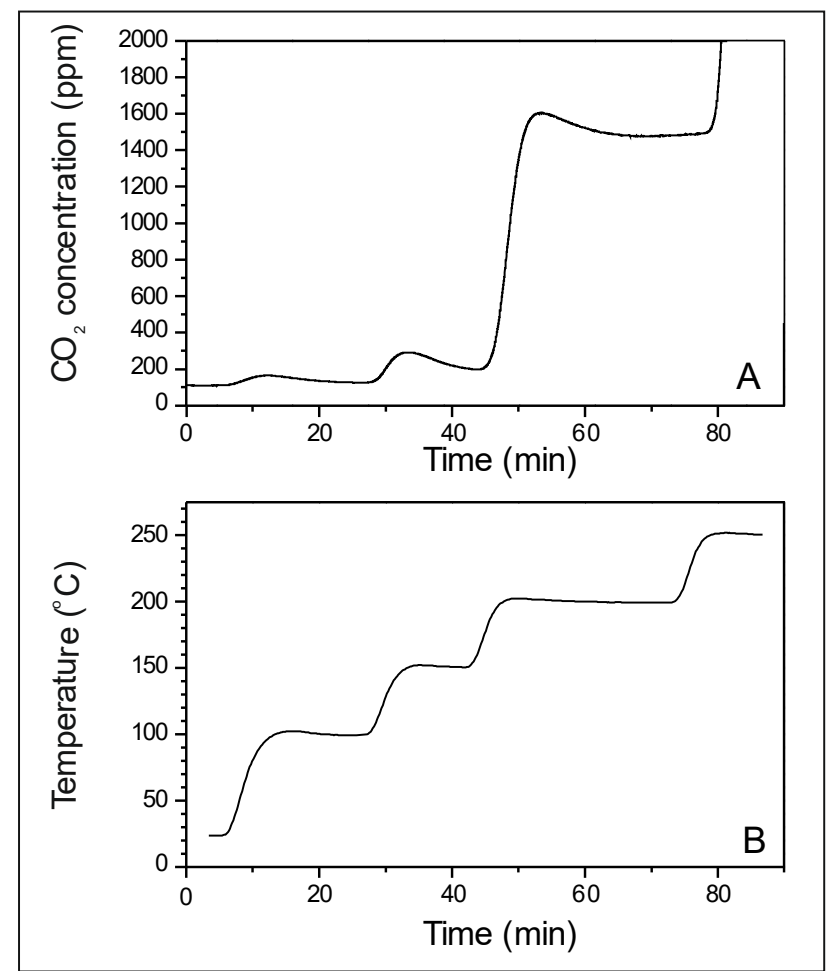

Fig. 1. Estimation of the experiment's temperature range (experiments with artificial air). $\mathrm{CO}_{2}$ emission $(A)$ at the temperature increase $(B)$ in pine wood experiment.

emission. For temperature values $<200^{\circ} \mathrm{C}$, detected traces of $\mathrm{CO}_{2}$ were below recommended operational range of Picarro Analyzer (100 ppm) and its absolute values must be treated with caution. $\mathrm{CO}_{2}$ concentration increased to $1400 \mathrm{ppm}$ when the temperature was increased to $200^{\circ} \mathrm{C}$. After a short time, the concentration stabilized. During the next change of temperature, to $250^{\circ} \mathrm{C}$, the $\mathrm{CO}_{2}$ concentration increased beyond the Picarro Analyzer limit (4000 ppm).

Second indicator of reaction intensity was the mass loss during combustion (Fig. 2). Wood samples were placed in the furnace, and the temperature was increased in $100^{\circ} \mathrm{C}$ intervals from 100 to $600^{\circ} \mathrm{C}$. Only the experiment with pine wood showed weight loss at temperatures below $200^{\circ} \mathrm{C}$ (Fig. 2). For samples of beech, oak and fossil oak, weight loss appeared between 200 and $300^{\circ} \mathrm{C}$. The weight loss, up to $600^{\circ} \mathrm{C}$, for samples of pine wood was $70 \%$, while for the beech, oak and fossil oak it was smaller, ca. $40-50 \%$ (Fig. 2).

The results suggest that the $\mathrm{B} / \mathrm{P}$ reaction started at $200-250^{\circ} \mathrm{C}$ for oak and beech, and below $200^{\circ} \mathrm{C}$ for pine. Taking this information into account, further experiments with the furnace were performed in the $200-600^{\circ} \mathrm{C}$ range.

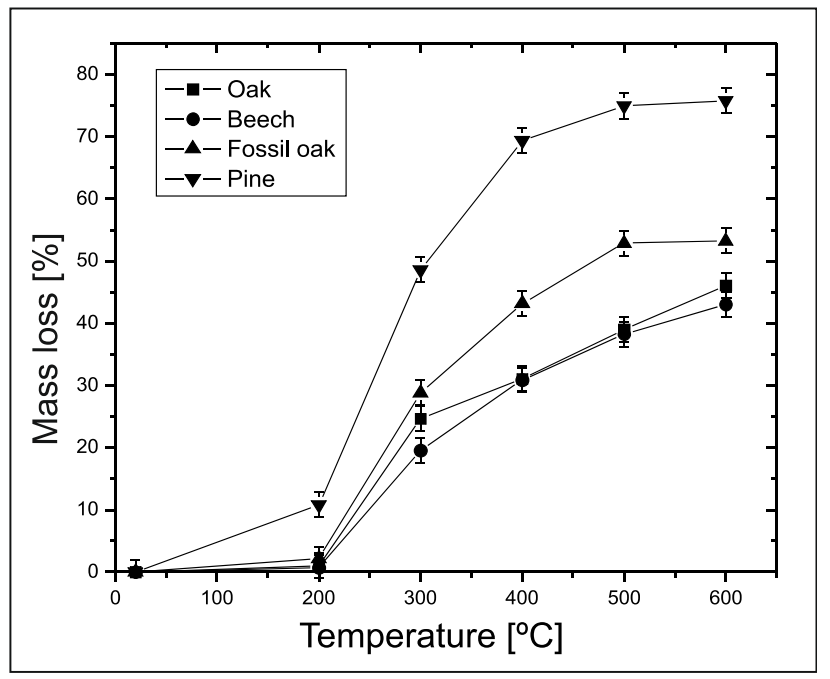

Fig. 2. Estimation of the experiment's temperature range (experiments with artificial air). Mass loss in the furnace experiments with modern wood.

\section{Carbon isotopic composition of combustion and pyroly- sis products}

Two heating experiments in the furnace have been performed, the first one, under a $\mathrm{N}_{2}$ atmosphere and the second one, in synthetic air (free of $\mathrm{CO}_{2}$ ). Examples of results obtained for pine wood are presented in Fig. 3. All obtained results indicate that there were no differences between the carbon isotopic composition of combustion (experiment with synthetic air) and low temperature pyrolysis (experiment in $\mathrm{N}_{2}$ ). Basing on these results we focused on combustion process (experiments with synthetic air, free of $\mathrm{CO}$ and $\mathrm{CO}_{2}$ ).

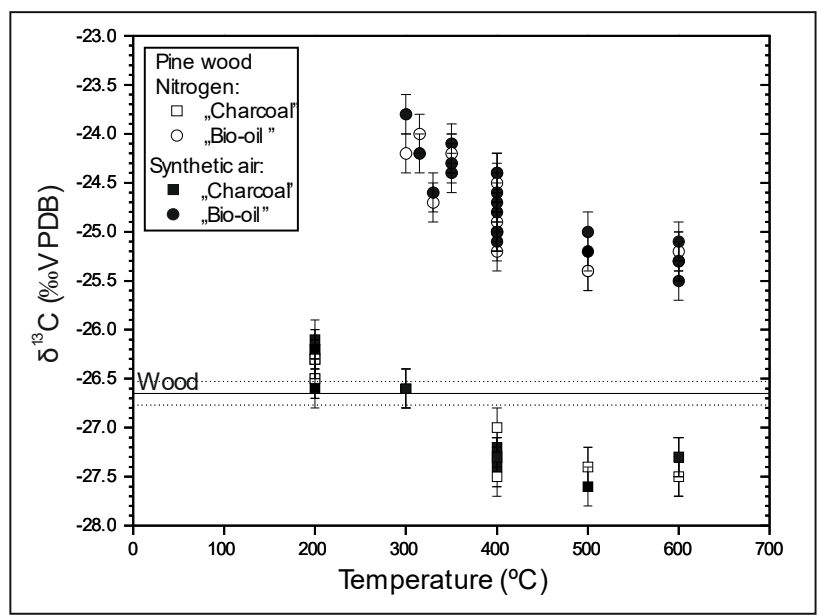

Fig. 3. Carbon isotopic composition of combustion and lowtemperature pyrolysis products from pine wood experiments. 
Carbon stable isotope composition of the wood combustion products

The first series of experiments were done using burning chamber as simulation of natural fireplace condition. The carbon isotopic composition values of the combustion products (three independent analyses for each one) from natural fireplace simulation are presented in Fig. 4. Calculated "variation factor" $(\Delta \mathrm{C})$ with $95 \%$ confidence ranges are presented in Table 2.

The carbon dioxide for all wood types, except beech, was enriched in ${ }^{13} \mathrm{C}$ relatively to the original wood. Values of $\Delta \mathrm{C}$ for $\mathrm{CO}_{2}$ achieved $0.90 \pm 0.38 \%$ and $3.39 \pm 0.21 \%$ for pine and fossil oak, respectively. The volatile burning products collected after condensation onto the quartz-glass plate were slightly enriched in ${ }^{13} \mathrm{C}$ for pine and oak $(\Delta \mathrm{C}$ values up to $0.4 \%$ and $0.8 \%$ respectively) and depleted for fossil oak and beech $(\Delta \mathrm{C}$ values up to $-0.5 \%$ ). The charred wood ("charcoal") and "ash" samples were generally depleted in ${ }^{13} \mathrm{C}$ relatively to the original wood, except for oak, where differences were in the range of uncertainty.

Next set of experiments with the furnace allowed for investigation of liquid combustion products ("acids" and "bio-oils"). The results of these experiments are presented in Fig. 5 and calculated $\Delta \mathrm{C}$ values with $95 \%$ confidence intervals in Table 3.

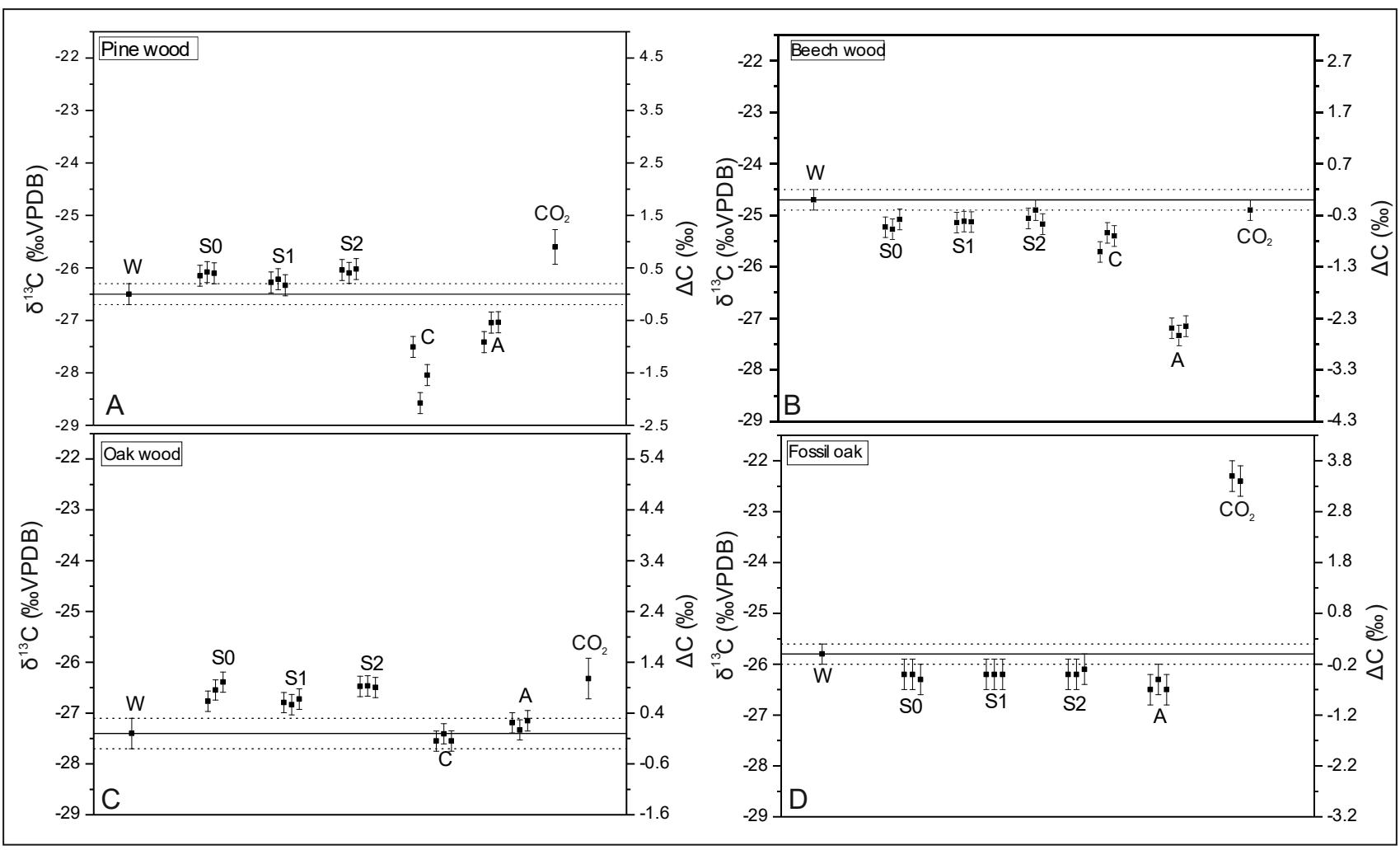

Fig. 4. Carbon stable isotope composition of combustion products from experiments in burning chamber. W-wood; SO - soot with no pre-treatment; $\mathrm{S} 1$ - soot pretreated by $\mathrm{HCl}$; $\mathrm{S} 2$ - soot pretreated by $\mathrm{HCl}$ and $\mathrm{HF} ; \mathrm{C}$ - "charcoal"; $\mathrm{A}$ - "Acid"; $\mathrm{CO}_{2}$ - carbon dioxide.

Table 2. "Variation factor" of wood burning products from combustion chamber experiments with estimated 95\% confidence intervals*.

\begin{tabular}{|c|c|c|c|c|}
\hline \multicolumn{5}{|c|}{ Variation factor $\Delta \mathrm{C}(\%)$} \\
\hline & Beech & Pinus & Oak & Fossil oak \\
\hline So (no pretreatment) & $-0.50 \pm 0.26$ & $0.39 \pm 0.28$ & $0.80 \pm 0.35$ & $-0.49 \pm 0.21$ \\
\hline $\mathrm{S} 1$ (pretreated with $\mathrm{HCl}$ ) & $-0.44 \pm 0.22$ & $0.22 \pm 0.28$ & $0.58 \pm 0.35$ & $-0.46 \pm 0.21$ \\
\hline $\mathrm{S2}$ (pretreated with $\mathrm{HCl}$ and $\mathrm{HF}$ ) & $-0.35 \pm 0.25$ & $0.45 \pm 0.28$ & $0.89 \pm 0.36$ & $-0.42 \pm 0.21$ \\
\hline Charcoal & $-0.79 \pm 0.26$ & $-1.54 \pm 0.28$ & $-0.13 \pm 0.36$ & \\
\hline Ash & $-2.53 \pm 0.25$ & $-0.66 \pm 0.28$ & $0.14 \pm 0.36$ & $-0.69 \pm 0.23$ \\
\hline $\mathrm{CO}_{2}$ & $-0.21 \pm 0.28$ & $0.90 \pm 0.38$ & $1.05 \pm 0.50$ & $3.39 \pm 0.21$ \\
\hline
\end{tabular}

*95\% confidence interval calculated by Monte Carlo simulation 

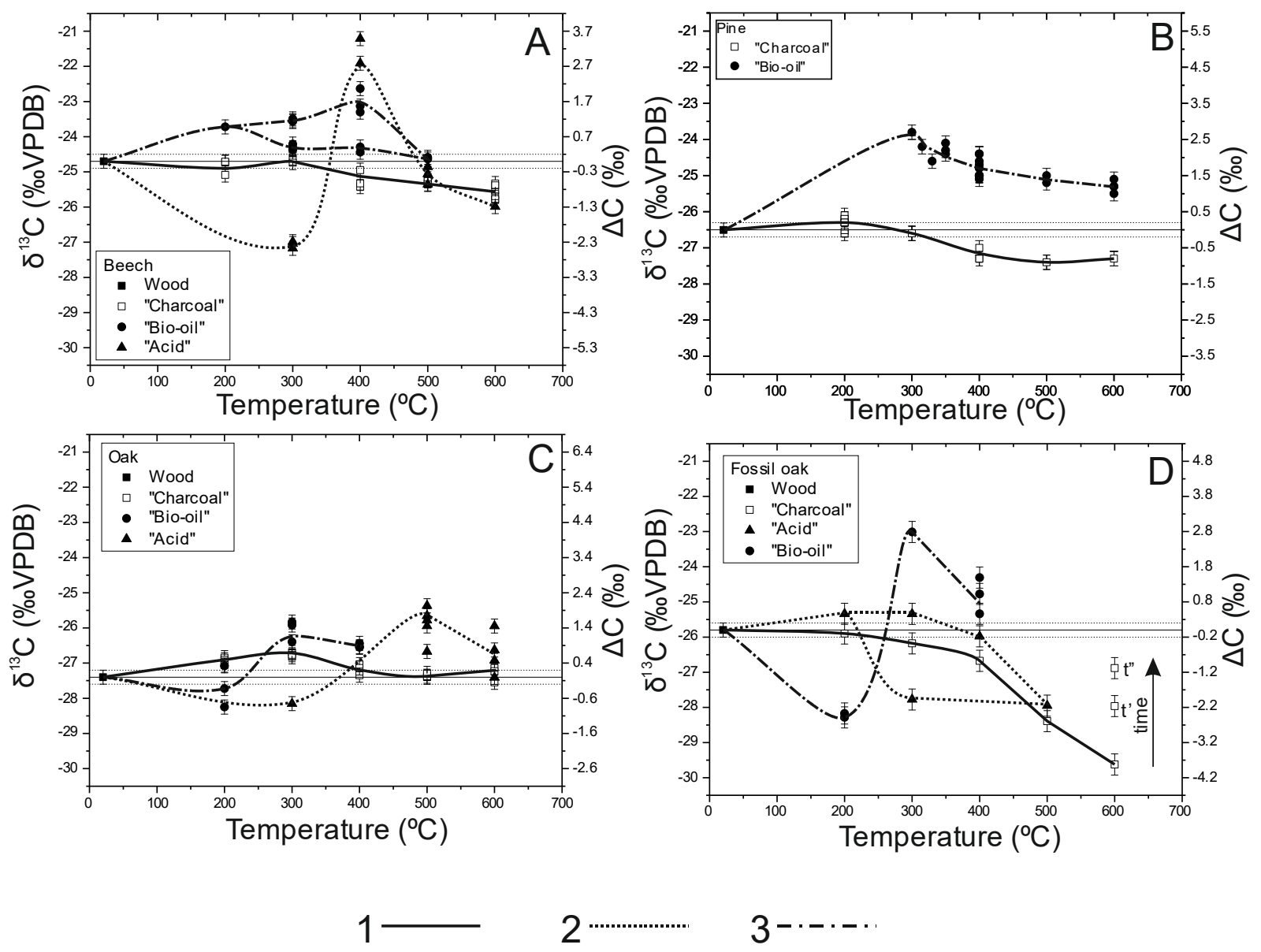

Fig. 5. Carbon stable isotope composition of combustion products from furnace experiments. 1, 2 and 3 - general trends of isotopic composition changes for "charcoal", "acids" and "bio-oil" fraction respectively.

At temperatures $>300^{\circ} \mathrm{C}$, the "charcoal" samples were depleted in ${ }^{13} \mathrm{C}$, except oak wood samples. The $\delta^{13} \mathrm{C}$ depletion was continuous as the temperature increased: it was relatively slow for lower temperatures (even with trends for enrichment at $200^{\circ} \mathrm{C}$ visibly for oak), and much faster above $400^{\circ} \mathrm{C}$.

After finishing the experiment with fossil oak, the "charcoal" was still reacted at $600^{\circ} \mathrm{C}$, and additional two samples were collected (Fig. 5), one after 60 min (marked as t'; $\Delta \mathrm{C}=-2.22 \pm 0.28 \%$ ) and one after $120 \mathrm{~min}$ (marked as t'; $\Delta \mathrm{C}=-1.14 \pm 0.28 \%$ ). These results indicate clear trend in the carbon isotopic composition towards heavier values as decomposition continued.

"Bio-oils" and "acids" exhibited differences in isotopic compositions at low and high combustion temperatures (Fig. 5). At low temperatures, there was a tendency toward $\delta^{13} \mathrm{C}$ depletion, while at $300^{\circ} \mathrm{C}\left(400^{\circ} \mathrm{C}\right.$ for beech), there was maximum of ${ }^{13} \mathrm{C}$ enrichment.
To test and to better understand the relationship between isotopic composition and burning time, another experiment was conducted at constant temperature. The oak wood sample was placed in the furnace preheated to $300^{\circ} \mathrm{C}$. "Bio-oil" and "acid" samples were collected for carbon isotopic composition analyses. After $150 \mathrm{~min}$, the release of "bio-oils" ended. The release of "acids" ended after $210 \mathrm{~min}$. After $250 \mathrm{~min}$, only small amounts of grey residuum were still left in the quartz tube. The results of carbon isotopic composition of collected burning products are presented in Fig. 6. After almost full wood decomposition, the remaining residuum was enriched in ${ }^{13} \mathrm{C}$ $(\Delta \mathrm{C}=1.5 \pm 0.37 \%)$. At the beginning of decomposition, there was an enrichment in ${ }^{13} \mathrm{C}$ in the released oils and acids. Shifts toward $\delta^{13} \mathrm{C}$ enrichment appeared for both the oils and acids as wood decay continued. Maximum enrichment levels were $1.27 \pm 0.36 \%$ for "bio-oils" after 60 minutes and $3.67 \pm 0.36 \%$ for "acid" after 210 minutes. 
Table 3. "Variation factor" of wood burning products from furnace experiments with estimated $95 \%$ confidence intervals*.

\begin{tabular}{|c|c|c|c|}
\hline \multicolumn{4}{|c|}{ Variation factor $\Delta \mathrm{C}(\%)$} \\
\hline \multicolumn{4}{|c|}{ Temperature experiment } \\
\hline & „Charcoal” & Oil & Acid \\
\hline \multicolumn{4}{|l|}{ Beech: } \\
\hline $200^{\circ} \mathrm{C}$ & $0.16 \pm 0.26$ & $0.97 \pm 0.29$ & \\
\hline $300^{\circ} \mathrm{C}$ & $0.12 \pm 0.25$ & $0.77 \pm 0.23$ & $-2.38 \pm 0.35$ \\
\hline $400^{\circ} \mathrm{C}$ & $-0.54 \pm 0.26$ & $1.13 \pm 0.33$ & $3.12 \pm 0.54$ \\
\hline $500^{\circ} \mathrm{C}$ & $-0.58 \pm 0.26$ & $0.08 \pm 0.28$ & $-0.40 \pm 0.27$ \\
\hline $600^{\circ} \mathrm{C}$ & $-0.91 \pm 0.26$ & & $-1.30 \pm 0.28$ \\
\hline \multicolumn{4}{|l|}{ Pine: } \\
\hline $200^{\circ} \mathrm{C}$ & $0.21 \pm 0.18$ & & \\
\hline $300^{\circ} \mathrm{C}$ & $-0.07 \pm 0.24$ & $2.44 \pm 0.28$ & \\
\hline $350^{\circ} \mathrm{C}$ & & $2.30 \pm 0.22$ & \\
\hline $400^{\circ} \mathrm{C}$ & $-0.76 \pm 0.19$ & $1.81 \pm 0.26$ & \\
\hline $500^{\circ} \mathrm{C}$ & $-0.92 \pm 0.27$ & $1.29 \pm 0.27$ & \\
\hline $600^{\circ} \mathrm{C}$ & $-0.86 \pm 0.21$ & $1.27 \pm 0.20$ & \\
\hline \multicolumn{4}{|l|}{ Oak: } \\
\hline $200^{\circ} \mathrm{C}$ & $0.43 \pm 0.36$ & $-0.32 \pm 0.39$ & \\
\hline $300^{\circ} \mathrm{C}$ & $0.61 \pm 0.36$ & $1.76 \pm 0.37$ & $-0.16 \pm 0.42$ \\
\hline $400^{\circ} \mathrm{C}$ & $0.19 \pm 0.36$ & $1.31 \pm 0.31$ & \\
\hline $500^{\circ} \mathrm{C}$ & $0.01 \pm 0.35$ & & $1.48 \pm 0.32$ \\
\hline $600^{\circ} \mathrm{C}$ & $0.06 \pm 0.36$ & & $0.64 \pm 0.37$ \\
\hline \multicolumn{4}{|l|}{ Fossil oak: } \\
\hline $200^{\circ} \mathrm{C}$ & $-0.16 \pm 0.28$ & $-2.48 \pm 0.22$ & $0.40 \pm 0.28$ \\
\hline $300^{\circ} \mathrm{C}$ & $-0.43 \pm 0.28$ & $2.73 \pm 0.29$ & $-0.81 \pm 1.73$ \\
\hline $400^{\circ} \mathrm{C}$ & $-0.93 \pm 0.28$ & $0.94 \pm 0.56$ & $-0.23 \pm 0.28$ \\
\hline $500^{\circ} \mathrm{C}$ & $-2.64 \pm 0.29$ & & $-2.21 \pm 0.28$ \\
\hline \multirow[t]{7}{*}{$600^{\circ} \mathrm{C}$} & $-3.88 \pm 0.29$ & & \\
\hline & $-2.22 \pm 0.28$ & & \\
\hline & (after 60 minutes & & \\
\hline & marked as t') & & \\
\hline & $-1.14 \pm 0.28$ & & \\
\hline & (after 120 minutes & & \\
\hline & marked as t') & & \\
\hline \multicolumn{4}{|c|}{ Time experiment } \\
\hline & „Charcoal” & Oil & Acid \\
\hline 15 minutes & & $0.83 \pm 0.36$ & $0.07 \pm 0.36$ \\
\hline 30 minutes & & $1.20 \pm 0.36$ & \\
\hline 45 minutes & & $1.16 \pm 0.36$ & $0.62 \pm 0.36$ \\
\hline 60 minutes & & $1.27 \pm 0.36$ & $0.50 \pm 0.36$ \\
\hline 90 minutes & & $0.75 \pm 0.36$ & $1.45 \pm 0.36$ \\
\hline 150 minutes & & $0.97 \pm 0.36$ & $2.46 \pm 0.36$ \\
\hline 210 minutes & & & $3.67 \pm 0.36$ \\
\hline 250 minutes & $1.51 \pm 0.37$ & & \\
\hline
\end{tabular}

*95\% confidence interval calculated by Monte Carlo simulation

\section{Molecular simulations}

\section{B/P of cellulose and lignin models}

In the first set of simulations' results, there is visible a significant difference between temperatures of the onset of pyrolysis in comparison to corresponding temperatures in the experiments. This is related to much faster ramp heating rate of the molecular simulations $(\sim 2$ ns to reach maximum temperature $v s$. several minutes/hours in the

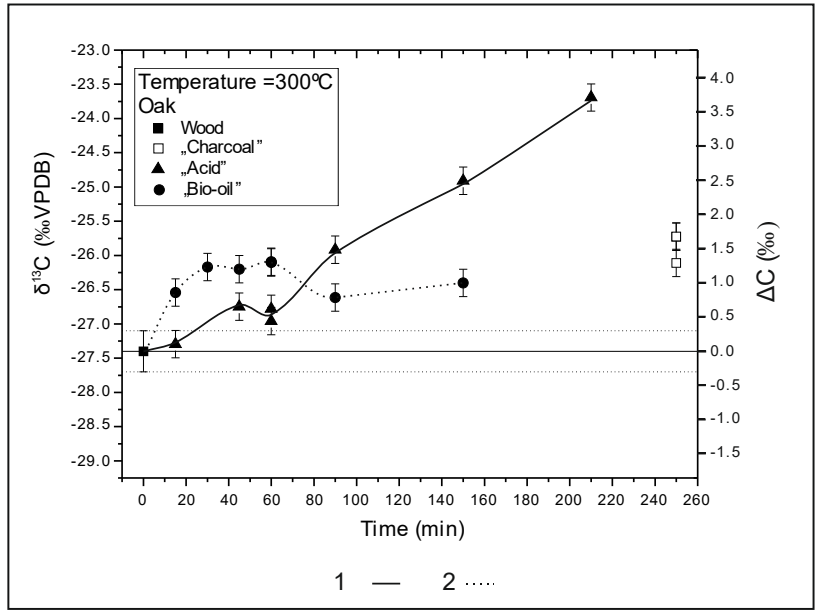

Fig. 6. Carbon stable isotope composition of combustion products from "time relationship" experiments. General trends for: 1. "Acids"; 2. "Bio-oils".

experiments). Similar results were obtained in modelling of pyrolysis of cellulose by Zhang et al. (2016). In spite of this temperature shift, results of ramp heating for different molecules but with the same rate can be compared to each other.

The first set of molecular simulations showed that reactions of thermal decomposition of cellulose and lignin are similar without (Fig. 7A and 7B) and with existence of gaseous oxygen (Fig. 7C and 7D). Cellulose decomposition begins at relatively lower temperatures. The reaction of breaking of its structure occurs at $c a$. 1000 $1300^{\circ} \mathrm{C}$ leading to formation of fractions that contain less than 7 carbon atoms. The amount of $\mathrm{C}_{4}-\mathrm{C}_{7}$ fraction is decreasing with temperature along with increase of content of lighter molecules $\left(\mathrm{C}_{0}-\mathrm{C}_{1}\right.$ and $\left.\mathrm{C}_{2}-\mathrm{C}_{3}\right)$.

In the Fig. $7 \mathrm{C}$ and $7 \mathrm{D}$ at lower temperatures there is formation of hydrogen bonds between hydrogen of lignin/cellulose and oxygens of $\mathrm{O}_{2}$ (visible as content of cellulose/lignin above $100 \%$ ). It is because cutoff for building molecules was set at $1.8 \mathrm{~A}$, which was close to distance of $\mathrm{O} \ldots \mathrm{H}-\mathrm{C}, \mathrm{O} \ldots \mathrm{H}-\mathrm{O}$ in hydrogen bonds. In the case of lignin $\mathrm{B} / \mathrm{P}$, significant decomposition of the structure occurs stepwisely at wide range of temperatures: from 1000 to $1800^{\circ} \mathrm{C}$ - these are equal or much higher than in the case of cellulose. Moreover, in the newly formed $\mathrm{B} / \mathrm{P}$ products a significant content of heavier $\mathrm{C}_{13}-\mathrm{C}_{30}$ and $\mathrm{C}_{8}-\mathrm{C}_{12}$ fractions were found.

\section{Isotope exchange between liquid/gaseous products and model of residuum}

Table 4 shows calculated $\Delta$ energies, $\Delta$ enthalpies and $\Delta$ Gibbs free energies along with thermal corrections for model isotope exchange reactions 3.2-3.5 at different temperatures. Using the following equation, it is possible to calculate isotopic effect:

$K=\alpha=\exp \left(\frac{-\Delta G_{\text {thermal }}}{R T}\right)$ 


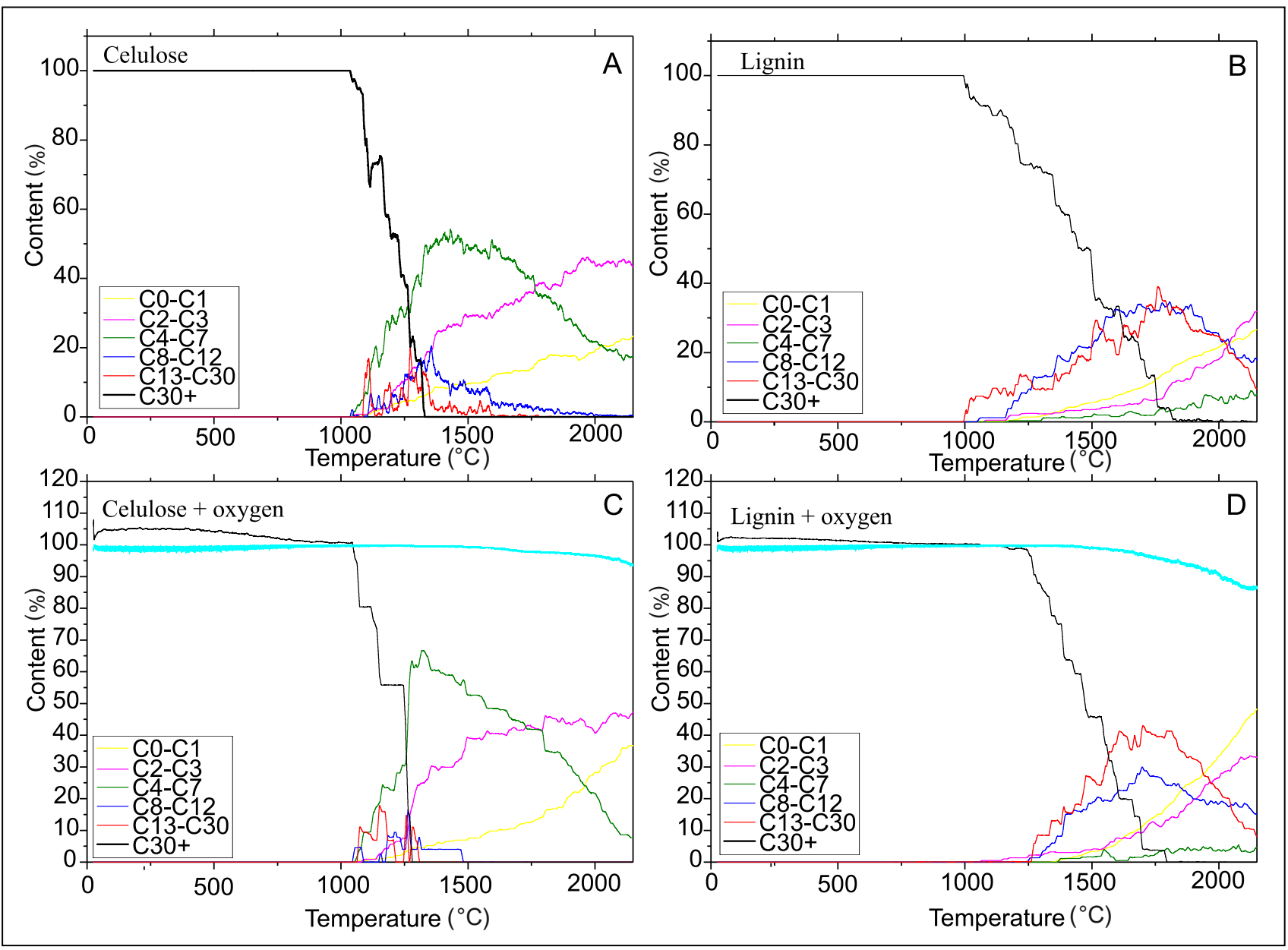

Fig. 7. Comparison of cellulose and lignin decomposition and decomposition products evolution with temperature $\left(1^{\circ} \mathrm{C} / \mathrm{ps}\right)$ basing on molecular simulations.

where $\mathrm{K}$ - equilibrium constant for reaction, in general $\alpha=\mathrm{K}^{1 / \mathrm{n}}$ where $\mathrm{n}$ is a number of exchanged atoms (if $\mathrm{n}=1$ then $\mathrm{K}=\alpha$ ); $\mathrm{R}$ - ideal gas constant; $\mathrm{T}$ - temperature.

Positive/negative values of energies indicates that the reactants are more/less stable than the products, respectively. Isotopically heavier gaseous/liquid products of $\mathrm{B} / \mathrm{P}$ were always considered as reactants (reactions 3.23.5). This means that, if assuming equilibrium in exchange between pyrene residuum and $\mathrm{CO}_{2}$, this gaseous molecule should always be enriched in heavier carbon isotope. Relationships with temperature is different for other organic molecules: formaldehyde $\left(\mathrm{C}_{1}\right.$ phase $)$ and glycolaldehyde $\left(\mathrm{C}_{2}\right.$ phase $)$ are depleted in ${ }^{13} \mathrm{C}$ at lower temperatures, while enriched at higher temperatures $>427^{\circ} \mathrm{C}(700 \mathrm{~K})$. Acetone $\left(\mathrm{C}_{3}\right.$ phase $)$ is expected to be depleted in ${ }^{13} \mathrm{C}$ even at higher pyrolysis temperatures.

There are three main sources of isotopic effect for the studied reactions 3.2-3.5:

- Zero-point energy (ZPE) correction, which arises from the fact that the lowest possible energy of the molecule at temperature of $0 \mathrm{~K}$ is not the electronic energy but is higher and is related to molecular vibra- tions. Influence of this correction is different for $\mathrm{CO}_{2}$ (positive) than for other product molecules (negative) in comparison to pyrene (Table 4 - third column).

- Thermal corrections, which are result of occupation of certain vibrational and rotational energy levels by molecules at considered temperatures (supplementary materials contains table with listed all thermal corrections). In the case of all the studied reactions 3.2-3.5 this effect leads to enrichment of gaseous/liquid products in ${ }^{13} \mathrm{C}$, comparing to energy levels that takes into account only ZPE (Table 4 - fourth column).

- Differences in entropy. Generally, higher entropy is observed for isotopically heavier molecules (supplementary materials contains table with translational, rotational and vibrational contributions to entropy). Based on the received results it is visible that in the case of all reactions 3.2-3.5 there is a decrease of entropy (Table 4), which according to relation: $\Delta \mathrm{G}=\Delta \mathrm{H}-\mathrm{T} \Delta \mathrm{S}$

leads to increase of $\Delta \mathrm{G}$, and thus indicates relative enrichment of gaseous/liquid products in ${ }^{13} \mathrm{C}$ (preferen- 
Table 4. Differences in energies and entropy of reactants and products for reactions 3.2-3.5 (in $\mathrm{kJ} / \mathrm{mol}$ and $\mathrm{J} / \mathrm{mol} \cdot \mathrm{K}$, respectively) for temperatures of $27^{\circ} \mathrm{C}(300 \mathrm{~K})$ and $427^{\circ} \mathrm{C}(700 \mathrm{~K})$ recalculated for one carbon atom, along with equilibrium constants.

\begin{tabular}{|c|c|c|c|c|c|c|}
\hline reaction & temperature $\left({ }^{\circ} \mathrm{C}\right)$ & $\Delta \mathrm{EZPE}^{*}$ & $\Delta \mathrm{E}_{\text {thermal }}{ }^{* *}$ & $\Delta G_{\text {thermal }}{ }^{* \star *}$ & $\Delta \mathbf{S}^{\star * \star *}$ & $\mathrm{~K}^{\star \star \star \star \star \star}$ \\
\hline \multirow{2}{*}{$\left(3.2-\mathrm{CO}_{2}\right)$} & 27 & 0.02998 & 0.03427 & 0.06128 & -0.08033 & 24.87 \\
\hline & 427 & 0.02998 & 0.08385 & 0.07265 & 0.01423 & 12.56 \\
\hline \multirow{2}{*}{ (3.3 - formaldehyde) } & 27 & -0.13872 & -0.08699 & -0.02306 & -0.21004 & -9.20 \\
\hline & 427 & -0.13872 & -0.00577 & 0.01466 & -0.02761 & 2.52 \\
\hline \multirow{2}{*}{ (3.4 - glycoaldehyde) } & 27 & -0.10346 & -0.05799 & -0.00923 & -0.15648 & -3.69 \\
\hline & 427 & -0.10346 & 0.00692 & 0.02142 & -0.01799 & 3.69 \\
\hline \multirow{2}{*}{ (3.5 - acetone) } & 27 & -0.08424 & -0.06414 & -0.03097 & -0.39204 & -12.34 \\
\hline & 427 & -0.08424 & -0.02422 & -0.00730 & -0.52635 & -1.25 \\
\hline
\end{tabular}

All energies in $\mathrm{kcal} / \mathrm{mol} ;{ }^{*} \Delta$ Energy $+\mathrm{ZPE} ;{ }^{* *} \Delta$ Energy + thermal correction; ${ }^{* * *} \Delta$ Gibbs Free Energy + thermal correction; ${ }^{* * *} \Delta$ Entropy; ${ }^{* * * * *}$ calculated based on equation 4.1 .

tial shift of all the 3.2-3.5 reactions to left side - towards reactants). Generally, at constant pressure:

$\Delta \mathrm{H}=\Delta \mathrm{E}-\mathrm{p} \Delta \mathrm{V}$

$\mathrm{p}$ - pressure; $\Delta \mathrm{V}$ - difference in volume between substrates and products. Because there is no difference in volume of the molecules substituted with different carbon isotopes: $\Delta \mathrm{V}=0$ and therefore in all calculations $\Delta \mathrm{H}=\Delta \mathrm{E}$.

Summarizing all the three contributions to isotopic effect (Table 4 - fifth column): at higher temperatures there is possibility of reversal of preferential isotope equilibria comparing to those from lower temperatures, which is due to the effects of differences both in entropy and thermal corrections to energy.

\section{DISCUSSION}

The isotopic composition of the $\mathrm{B} / \mathrm{P}$ products depended first on the isotopic composition of the initial material. The wood samples studied are typical terrestrial plants that use a $\mathrm{C}_{3}$ photosynthesis pathway. The typical $\delta^{13} \mathrm{C}$ value for $\mathrm{C}_{3}$ plants is in the range from $-25 \%$ to $-32 \%$ (mean 28\%; Wickman, 1952; Baertschi, 1953 and Craig, $1953,1954)$ and the carbon isotopic composition of the wood samples used in this study agrees with these data.

Wood is a complex material and consists of several phases with different carbon isotopic composition. The major wood components, cellulose and lignin, differ by $4-7 \%$. Cellulose is enriched by $1-2 \%$, and lignin is depleted by $2-6 \%$ relatively to the whole wood composition (Benner et al., 1987). These main wood components also have different $\mathrm{B} / \mathrm{P}$ characteristics (Rowell and LeVan-Green, 2005). Whole wood thermal degradation starts below $250^{\circ} \mathrm{C}$. At $300-375^{\circ} \mathrm{C}$, most of the carbohydrate polymers, except lignin, are degraded. Hemicellulose decomposition starts at $c a .225^{\circ} \mathrm{C}$ and is almost completed by $325^{\circ} \mathrm{C}$. The cellulose is more stable, and its most intensive degradation takes place in a short temperature range above $370^{\circ} \mathrm{C}$ (Rowell and LeVan-Green, 2005). The main component of the wood cell wall is cellulose and its degradation characteristics dominate the process of wood B/P (Shafizadeh, 1984 and Rowell and LeVan-Green, 2005). The main products of cellulose degradation are volatile gases, while the main lignin decomposition products are tar and char (Rowell and LeVan-Green, 2005). Different carbon isotopic composition of component with different $\mathrm{B} / \mathrm{P}$ characteristic may be a key for interpretation of our experiments results.

The experiments performed in this study show that the $\mathrm{B} / \mathrm{P}$ initiation temperature is dependent on the type of wood. For the beech and oak, B/P decomposition starts at $200-250^{\circ}$, while for pine at lower temperatures $\left(<200^{\circ} \mathrm{C}\right)$. This agrees with results of Shafizadeh (1984) and Rowell and LeVan-Green (2005).

\section{Variation in isotopic composition of $B / P$ products depending on temperature}

General trends of carbon isotopic changes in $\mathrm{B} / \mathrm{P}$ products obtained in experiments agree with results published earlier by different authors. In general, it is agreed that the isotopic composition of charcoal differs from wood by up to 2\%o (Ferrio et al., 2006; Turney et al., 2006; Ascough et al., 2008; Das et al., 2010 and Bird and Ascough, 2012). It is also agreed that it is temperature dependent. Below $300^{\circ} \mathrm{C}$, there is an increase in $\delta^{13} \mathrm{C}$ in charcoal, which is interpreted as a loss of isotopically lighter phases and/or more resistance of isotopically heavier cellulose (Jones et al., 1993; Czimczik et al., 2002; Poole et al., 2002; Hakkou et al., 2006 and Bird and Ascought, 2012). Above $300^{\circ} \mathrm{C}$, charcoal is depleted by $1-2 \%$ relatively to wood (Jones and Chaloner, 1991; Jones et al., 1993; Bird and Grocke, 1997; Czimczik et al., 2002; Turney et al., 2006; Ascought et al., 2008 and Bird and Ascought, 2012). This is explained by the preferential decomposition of isotopically heavier cellulose. Above $400^{\circ} \mathrm{C}$, further ${ }^{13} \mathrm{C}$ depletion is interpreted as caused by preferential loss of ${ }^{13} \mathrm{C}$ during $\mathrm{C}=\mathrm{C}$ bond formation in polyaromatization (Qian et al., 1992 and Krull et al., 2003). Effect of temperature relation between charcoal (residuum) $\delta^{13} \mathrm{C}$ and temperature were visible in the results of presented studies (experiments with furnace). Initially, at temperatures $<300^{\circ} \mathrm{C}$, we observed an in- 
crease in $\delta^{13} \mathrm{C}$, with maximum values at $300^{\circ} \mathrm{C}\left(200^{\circ} \mathrm{C}\right.$ for pine) but isotopic variation factor $(\Delta \mathrm{C})$ values were significant only for oak and pine $\left(\Delta \mathrm{C}_{200}\right.$ were $0.43 \pm 0.36 \%$ and $0.21 \pm 0.18 \%$ and t-values for Student tests were 2.479 and 2.453 , respectively; critical value is 2.032). At higher temperatures, the $\delta^{13} \mathrm{C}$ values decreased until $500^{\circ} \mathrm{C}$, and then stabilized for pine and modern oak. For all wood types, except oak, $\delta^{13} \mathrm{C}$ depletion was significant at the temperature $400^{\circ} \mathrm{C}$ and above (Table 3). The biggest differences between charcoal and wood $\delta^{13} \mathrm{C}$ was for fossil oak depletion at the high temperature $\left(\Delta \mathrm{C}_{600}\right.$ were $-3.88 \pm 0.29 \%$ and t-values for Student tests were 18.786 and critical value 2.201) Experiment with fossil oak was extended for additional 120 minutes and an extended period of wood decomposition at $600^{\circ} \mathrm{C}$, caused a significant increase in the $\delta^{13} \mathrm{C}$ value (Fig. 5D and Table 3 ) from $-3.88 \pm 0.29 \%$ to $-2.22 \pm 0.28 \%$ (after additional 60 minutes) and $-1.14 \pm 0.28 \%$ (after next 120 minutes).

In the furnace experiments, the samples of "acids"/"bio-oils" were collected from the material condensed on the cool surface of the quartz sample tube. Like for "charcoal", the carbon isotopic composition of these products is temperature dependent (Fig. 5). Depletion in ${ }^{13} \mathrm{C}$ of "bio-oils" samples for fossil oak at lower temperatures $\left(200^{\circ} \mathrm{C}\right)$ may suggests light isotopically phases as a primary wood component of the source of these materials. But, beech "bio-oils" samples at $200^{\circ} \mathrm{C}$ are enriched in ${ }^{13} \mathrm{C}(\Delta \mathrm{C}=0.97 \pm 0.29 \%)$. Similarly, "acids" samples from fossil oak at $200^{\circ} \mathrm{C}$ are enriched in ${ }^{13} \mathrm{C}$ $(\Delta \mathrm{C}=0.40 \pm 0.28 \%)$. Other results obtained for $200^{\circ} \mathrm{C}$ are statistically nonsignificant. For the range $300-500^{\circ} \mathrm{C}$, "bio-oils" and "acids" are enriched in ${ }^{13} \mathrm{C}$, suggesting heavier cellulose components as a primary material. These results lend further support to the literature explanations for charcoal carbon isotopic fractionation, where preferential decomposition of lighter phases is observed at lower temperatures and heavier cellulose degrades at higher temperatures (Jones and Chaloner, 1991; Jones et al., 1993; Bird and Grocke, 1997; Czimczik et al., 2002; Poole et al., 2002; Hakkou et al., 2006; Turney et al., 2006; Ascought et al., 2008 and Bird and Ascought, 2012).

Performed molecular simulations offers another alternative explanation of isotopic variation of $\mathrm{B} / \mathrm{P}$ products. Results of simulations of isotope exchange between gaseous/liquid products and model of residuum show significant differences of equilibrium constant for exchange reaction (e.g. 3.2-3.5) depending on temperature (Table 4). This can lead to depletion of ${ }^{13} \mathrm{C}$ in gaseous/liquid products for lower temperatures and enrichment for higher ones. Overally, this will lead to opposite trends in ${ }^{13} \mathrm{C}$ content variation for residuum ("charcoal"), eventually giving depleted solid product. In our opinion, this alternative explanation can be superimposed on differences in decomposition of various wood components and the final isotopic composition of $\mathrm{B} / \mathrm{P}$ products is also resultant of evolution of temperature during combustion.
Significant differences between $\delta^{13} \mathrm{C}$ of charcoal produced by pyrolysis and incomplete combustion reported in published studies were explained by the acceleration of cellulose decomposition by pyrolysis in comparison to decomposition in the presence of $\mathrm{O}_{2}$ (Turney et al., 2006; Ascough et al., 2008; Das et al., 2010 and Bird and Ascough, 2012). The experiments with pine wood (Fig. 3) do not show differences in the carbon isotopic composition of "charcoal" and "bio-oils" in pyrolysis (in $\mathrm{N}_{2}$ ) and heating in the presence of $\mathrm{O}_{2}$ (burning in artificial $\mathrm{CO}_{2}$-free air). This result is also supported by molecular simulations showing that decomposition of model of cellulose and lignin is very similar with and without existence of additional $\mathrm{O}_{2}$ (Fig. 7).

\section{Variation in isotopic composition of $B / P$ products in process duration}

Published B/P experimental results for $\delta^{13} \mathrm{C}$ values of charcoal suggested no time dependence of the carbon isotopic composition (Turney et al., 2006; Ascough et al., 2008; Das et al., 2010 and Bird and Ascough, 2012). The $\mathrm{B} / \mathrm{P}$ experiment with oak at $300^{\circ} \mathrm{C}$ showed significant changes in isotopic composition of incomplete burning products with time (Table 3 and Fig. 6). The continuous decomposition of wood with time reflects the thermal stability of each wood component. Initially, after $15 \mathrm{~min}$, "oils" were enriched in $\delta^{13} \mathrm{C}(\Delta \mathrm{C}=0.83 \pm 0.36 \%)$ and acids was not showing isotopic fractionations $(\Delta \mathrm{C}=$ $0.07 \pm 0.36 \%$; $t$-value for Student test was 0.24 and critical value 2.042). After 45 minutes acids were enriched in relation to wood composition $(\Delta \mathrm{C}=0.62 \pm 0.36 \%$; t-value was 2.28). After $90 \mathrm{~min} \mathrm{~B} / \mathrm{P}$ decomposition, acids have started to be more enriched in ${ }^{13} \mathrm{C}$ than oils. The maximum acid enrichment was achieved after $210 \mathrm{~min}$ in the last acid samples that could be collected $(\Delta \mathrm{C}=$ $3.67 \pm 0.36 \%$ ). After $60 \mathrm{~min}$ processing, oils showed a decrease in the level of enrichment. The cellulose was likely to be decomposed quickly, and its effect was only visible for a short time in the initial period of the decomposition. Later carbon isotopic composition was dominated by the more stable lignin and isotopically lighter than cellulose.

In the simulation of natural fireplace experiment the carbon isotopic composition of $\mathrm{CO}_{2}$ indicated enrichment in ${ }^{13} \mathrm{C}$ isotope relatively to "ash" (Fig. 3). This effect can be explained by means of molecular simulations. Assuming equilibrium in isotopic exchange between gas and residuum, $\delta^{13} \mathrm{C}$ values would be increased by $c a$. $20 \%$ (Table 4). Lower experimental $\delta^{13} \mathrm{C}$ values indicates that there is no equilibrium in isotopic exchange. The trend is however similar in experiments and in molecular simulations.

\section{Difference between fossil and modern oak wood}

In all the experiments, difference between fossil and modern oak wood is visible in the mass loss, carbon iso- 
topic composition of the $\mathrm{B} / \mathrm{P}$ products and its temperature dependence. For fossil oak, the $\delta^{13} \mathrm{C}$ value of the condensed volatiles was depleted $(\Delta \mathrm{C}$ around $-0.4 \%$; see Table 2) vs. the whole wood, while for modern oak it was enriched ( $\Delta \mathrm{C}$ around $0.8 \%$; see Table 2$)$. Probably, for the $\delta^{13} \mathrm{C}$ value of the condensed volatiles from fossil oak, lignin was the dominating initial component, while for fresh oak it was cellulose. These results can suggest that that, during wood fossilization, cellulose, the component enriched in ${ }^{13} \mathrm{C}$, was preferentially decomposed. A similar effect was reported for wood samples of different ages and occurrence conditions (Fengel and Munich, 1991). However, process of wood decomposition are dependent on the environmental condition at the time of fossilization. The relative carbon isotopic composition of volatiles collected on the glass plate was dependent on the wood type as a result of the proportional differences between cellulose and lignin. This is probably the reason for the different behaviour in the beech and pine wood experiments.

\section{CONCLUSIONS}

This study shows differences in the carbon isotopic composition of wood burning/pyrolysis products. The extreme values of the variation factor were around $-4 \%$ for charcoal from fossil oak at $600^{\circ} \mathrm{C}$ and around $3 \%$ for "acids" from beech wood at $400^{\circ} \mathrm{C}$. The typical range of variation was between $-2 \%$ and $2 \%$.

The carbon isotopic composition differentiation in $\mathrm{B} / \mathrm{P}$ products is temperature and time dependent. Variation factor values are wood type dependent, but general trends are similar for all types of modern wood examined (Fig. 5). The different behaviour of fossil oak in the $\mathrm{B} / \mathrm{P}$ decomposition process is a result of selective decomposition of some wood components during fossilization.

The observed temperature dependence for the carbon isotopic composition is a result of two effects. The first one is the different thermal stability of the main wood components, which are also characterized by different carbon isotopic composition. Thus, the less thermally stable and isotopically lighter lignin decomposition controls the isotopic composition of the $\mathrm{B} / \mathrm{P}$ products at the lower temperatures, while heavier cellulose is the dominant component at temperatures above $300^{\circ} \mathrm{C}$. Superimposed on this effect there can also be differences in isotopic composition of gaseous/liquid products that have significantly different equilibrium constants for reaction of isotopic exchange with residuum.

The experiment with $\mathrm{B} / \mathrm{P}$ decomposition of oak wood at $300^{\circ} \mathrm{C}$ shows the time dependence of the carbon isotopic composition for all $\mathrm{B} / \mathrm{P}$ products. It confirms that $\mathrm{B} / \mathrm{P}$ should be treated as a continuous process, with the results depending on the degree of process development.

This is especially important given the number of studies using the variation in the isotopic composition of combustion products as a record of paleoenvironmental change. Natural burning processes are dynamic and temperature, $\mathrm{O}_{2}$ availability and other conditions change rapidly. Collected burning products from geological or archaeological sites contain no information about temperature or other conditions of the burning process. It is especially important when studies are performed using samples of burning products separated from deposits as a dispersed organic material. The application of chemical pre-treatment methods necessary for burning products (e.g. soot aggregates) separation may introduce additional isotopic fractionation (see Table 2).

The differences in the carbon isotopic composition of the combustion products and its dependence on temperature or reaction time make it necessary to take great care in studies that use the isotopic composition of combustion products as a paleoenvironmental proxy or as an isotopic metric for the identification of source material.

\section{Future studies}

The differences in the isotopic composition of carbon in soot aggregates have become a motivation for expanding experimental research. The studies carried out do not provide definitive and sufficient answers to the questions posed, but they indicate the importance of the complex study of combustion products instead of focusing only on selected products. The most important seems to be the extension of the research to chemical analysis of $\mathrm{B} / \mathrm{P}$ products, especially volatile components condensing on collecting plates and gaseous products. Molecular simulations seem to be a good tool that can be particularly useful in explaining the differentiation of the carbon isotopic composition during $\mathrm{B} / \mathrm{P}$ processes. Finally, it is advisable to collect a larger number of research results so that it is possible to analyze the significance of the differences found, as well as the variability of the obtained results for a larger number of wood samples.

\section{ACKNOWLEDGMENTS}

The authors would like to thank the Reviewers for their constructive comments which helped us to improve the manuscript. The authors thank M. Krapiec for fossil oak wood samples and J. Partyka for beech wood samples. This work was supported by the Polish National Science Centre [grant number 2013/09/B/ST10/00040]. Tingting Zhang is also acknowledged for providing molecular model of lignin.

\section{SUPPLEMENTARY MATERIAL}

Supplementary material, containing additional Tables $\mathrm{S} 1$ and $\mathrm{S} 1$, is available online at https://doi.org/10.1515/geochr-2015-0110. 


\section{REFERENCES}

Ascough P, Bird MI, Wormald P, Snape CE and Apperlay D, 2008. Influence of pyrolysis variables and starting material on charcoal stable isotopic and molecular characteristics. Geochemica et Cosmochimica Acta 72: 6090-6102, DOI 10.1016/j.gca.2008.10.009.

Baertschi P, 1953. Die fraktionierung der naturlichen kohlenstoffisotopen im kohlendioxydstoffwechsel gruner pflanzen. Helvetica Chimica Acta 36: 773-781, DOI 10.1002/hlca. 19530360403.

Benington F, Melton C and Watson PJ, 1962. Carbon dating prehistoric soot from Salts Cave, Kentucky. American Antiquity 28: 238-241, DOI 10.2307/278384.

Benner R, Fogel ML, Sprague EK and Hodson RE, 1987. Depletion of $\delta 13 \mathrm{C}$ in lignin and its implication for stable isotope studies. Nature 329: 708-710, DOI 10.1038/329708a0.

Bird MI, 2006. Radiocarbon dating of charcoal. In: Elias SA, ed., The Encyklopedia of Quaternary Science. Elsevier, Amsterdam: 29502957.

Bird MI and Ascough PL, 2012. Isotopes in pyrogenic carbon. A review. Organic Geochemistry 42: 1529-1539, DOI 10.1016/j.orggeochem.2010.09.005.

Bird MI and Grocke D, 1997. Determination of the abundance and carbon-isotope composition of elemental carbon in sediments. $\mathrm{Ge}$ ochimica et Cosmochimica Acta 61: 3413-3423, DOI 10.1016/S0016-7037(97)00157-9.

Bird MI and Cali JA, 1998. A million-year record of fire in sub-Saharan Africa. Nature 394: 767-768, DOI 10.1038/29507.

Brodowski S, Amelung W, Haumaier L, Abetz C and Zech W, 2005. Morphological and chemical properties of black carbon in physical soil fractions as revealed by scanning electron microscopy and energy-dispersive X-ray spectroscopy. Geoderma 128: 116-129, DOI 10.1016/j.geoderma.2004.12.019.

Bronk-Ramsey C, 2009. Bayesian analysis of radiocarbon dates. Radiocarbon 51: 337-360, DOI 10.1017/S0033822200033865.

Cachier H, Bremond MP and Buat-Manard P, 1989. Determination of atmospheric soot carbon with a simple thermal method. Tellus B: Chemical and Physical Meteorology 41B: 379-390, DOI 10.1111/j.1600-0889.1989.tb00316.x.

Chang SJ, Jeong GY and Kim SJ, 2008. The origin of black carbon on speleothems in tourist caves in South Korea: Chemical characterization and source discrimination by radiocarbon measurement. Atmospheric Environment 42: 1790-1800, DOI 10.1016/j.atmosenv.2007.11.042.

Chenoweth K, Van Duin AC and Goddard WA, 2008. ReaxFF reactive force field for molecular dynamics simulations of hydrocarbon oxidation. The Journal of Physical Chemistry A 112: 1040-1053, DOI 10.1021/jp709896w.

Craig H, 1953. The geochemistry of the stable carbon isotopes. Geochimica et Cosmochimica Acta 3: 53-92, DOI 10.1016/00167037(53)90001-5.

Craig H, 1954. Carbon-13 in plants and the relationships between carbon-13 and carbon- 14 variations in nature. Journal of Geology 62: 115-149, DOI 10.1086/626141.

Cressler WL, 2001. Evidence of earliest known wildfires. Palaios 16: 171-174, $\quad$ DOI $10.1669 / 0883$ 1351(2001)016<0171:EOEKW>2.0.CO;2.

Currie LA, Eglinton TJ, Benner BA Jr and Pearson A, 1997. Radiocarbon "dating" of individual chemical compounds in atmospheric aerosol: first results comparing direct isotopic and multivariate statistical apportionment of specific polycyclic aromatic hydrocarbons. Nuclear Instruments and Methods in Physics Research B 123: 475-486, DOI 10.1016/S0168-583X(96)00783-5.

Czimczik CI, Preston CM, Schmidt MWI, Werner RA and Schultze ED, 2002. Effect of charring on mass, organic carbon and stable isotopic composition of wood. Organic Geochemistry 33: 1207-1223.

Czimczik CI, Schmidt MWI and Schulze ED, 2005. Effect of increasing fire frequency on black carbon and organic matter in Podzols of Siberian Scots pine forests. European Journal of Soil Sciences 56: 417-428, DOI 10.1111/j.1365-2389.2004.00665.x.
Das O, Wang Y and Hsieh YP, 2010. Chemical and carbon isotopic characteristics of ash and smoke derived from burning of $\mathrm{C}_{3}$ and $\mathrm{C}_{4}$ grasses. Organic Geochemistry 41: 263-269, DOI 10.1016/j.orggeochem.2009.11.001.

Dittmar T and Koch BP, 2006. Thermogenic organic matter dissolved in the abyssal ocean. Marine Chemistry 102: 208-217, DOI 10.1016/j.marchem.2006.04.003.

Dittmar T and Paeng J, 2009. A heat-induced molecular signature in marine dissolved organic matter. Nature Geoscience 2: 175-179, DOI 10.1038/NGEO440.

Eckmeier E, Gerlach R, Skjemstad JO, Ehrmann O and Schmidt MWI, 2007. Only small changes in soil organic carbon and charcoal found one year after experimental slash-and-burn in a temperature deciduous forest. Biogeosciences Discussions 4: 595-614.

Fengel D and Munich FRG, 1991. Aging and fossilization of wood and its components. Wood Science and Technology 25: 153-177.

Ferrio JP, Alonso N, Lopez JB, Araus JL and Voltas J, 2006. Carbon isotope composition of fossil charcoal reveals aridity changes in the NW Mediterranean basin. Global Change Biology 12: 1253 1266, DOI 10.1111/j.1365-2486.2006.01170.x.

Frisch M, Trucks G, Schlegel H, Scuseria G, Robb M, Cheeseman J, Montgomery J, Vreven J, Kudin K, Burant J, Millam J, Iyengar S, Tomasi J, Barone V, Mannucci B, Cossi M, Scalmani G, Rega N, Petersson G, Nakatsuji H, Hada M, Ehara M, Toyota K, Fukuda F, Hasegawa J, Ishida M, Nakajima T, Honda Y, Kitao O, Nakai H, Klene M, Li X, Knox J, Hratchian H, Cross J, Bakken V, Adamo C, Jramillo J, Gomperts R, Stratmann R, Yazyev O, Austin A, Cammi R, Pomelli C, Ochterski J, Ayala P, Morokuma K, Voth G, Salvador P, Dannenberg J, Zakrzewski V, Dapprich S, Daniels A, Strain M, Frakas O, Malick D, Rabuck A, Raghavachari K, Foresman J, Ortiz J, Cui Q, Baboul A, Clifford S, Cislowski J, Stefanov B, Liu G, Liashenko A, Piskorz P, Komaromi I, Martin R, Fox D, Keith T, Al-Laham M, Peng C, Nanayakkara A, Challacombe M, Gill P, Johnson B, Chen W, Wong M, Gonzalez C and Pople J, 2004. Gaussian-94, Revision, C.3,. Gaussian, Inc., Pittsburgh, PA.

Goldberg ED, 1985. Black Carbon in the Environment. John Wiley, New York: 198.

Gradziński M, Hercman H, Bella P, Debaene G, and Nowicki T, 2002. Tmavé laminácie v sintrových nátekoch jaskyne Domica ako indikátor akivít pravekých l'udí (Dark coloured laminae within speleothems of the Domica Cave as an indicator of the prehistoric men activity). Slovenský Kras 40: 41-48 (in Slovak).

Gradziński M, Gorny A, Pazdur A and Pazdur, MF, 2003. Origin of black coloured laminae in speleothems from the Kraków-Wielun, Upland, Poland. Boreas 32: 532-542, DOI 10.1080/03009480310003414.

Gradziński M, Hercman H, Nowak M and Bella P, 2007. Age of black coloured laminae within speleothems from Domica Cave and its significance for dating of prehistoric human settlement. Geochronometria 28: 39-45, DOI 10.2478/v10003-007-0029-7.

Haberstroh PR, Brandes JA, Gélinas Y, Dickens AF, Wirick S, Cody G, 2006. Chemical composition of the graphitic black carbon fraction in riverine and marine sediments at sub-micron scales using carbon X-ray spectromicroscopy. Geochimica et Cosmochimica Acta 70: 1483-1494, DOI 10.1016/j.gca.2005.12.001.

Hakkou M, Petrissan M, Gerardin P and Zoulalian A, 2006. Investigation of the reason for fungal durability of heat-treated beech wood. Polymer Degradation and Stability 91: 393-397, DOI 10.1016/j.polymdegradstab.2005.04.042.

Hall G, Woodborne S and Scholes M, 2008. Stable carbon isotope ratios from archaeological charcoal as palaeoenvironmental indicators. Chemical Geology 247: $384-400, \quad$ DOI 10.1016/j.chemgeo.2007.11.001.

Hill CA, 1982. Origin of black deposits in caves. National Speleological Society Bulletin 44: 15-19.

Joeng GY, Kim SJ and Chang SJ, 2003. Black carbon pollution of speleothems by fine urban aerosols in tourist caves. American Mineralogist 88: 1872-1878, DOI 10.2138/am-2003-11-1230.

Jones TP and Chaloner WG, 1991. Fossil charcoal, its recognition and palaoatmospheric significance. Palaeogeography, Palaeoclimatol- 
ogy, Palaeoecology 97: 39-50, DOI 10.1016/00310182(91)90180-Y.

Jones TP, Scott AC and Mattey DP, 1993. Investigations of "fusain transition fossils" from the Lower Carbiniferous: comparison with modern partially charred wood. International Journal of Coal Geology 22: 37-59, DOI 10.1016/0166-5162(93)90037-B.

Krull E, Skjemstad J, Graetz D, Grice K, Dunning W, Cook G and Parr $\mathrm{J}, 2003 .{ }^{13} \mathrm{C}$ depleted charcoal from $\mathrm{C}_{4}$ grasses and the role of occluded gases in phytolith. Organic Geochemistry 34: 1337-1352, DOI 10.1016/S0146-6380(03)00100-1.

Lehmann J, Skjemstad J, Sohi C, Carter J, Berson M, Fallon P, Coleman K, Woodbury P and Krull E, 2008. Australin climate-carbon cycle feedback reduced by soil black carbon. Nature Geosciences 1: $832-835$.

Manino A and Harvey HR, 2004. Black carbon in estuarine and coastal ocean dissolved organic matter. Limnology and Oceanography 49: 735-740, DOI 10.4319/1o.2004.49.3.0735.

Masiello CA, 2004. New direction in black carbon organic geochemistry. Marine Chemistry 92: 201-213, DOI 10.1016/j.marchem.2004.06.043.

Masiello CA and Druffe ERM, 1998. Black carbon in deep sea sediments. Science 280: 1911-1913, DOI 10.1126/science. 280.5371 .1911$.

Masiello CA, Druffel ERM and Currie LA, 2002. Radiocarbon measurements of black carbon in aerosols and ocean sediments. Geochimica et Cosmochimica Acta 66: 1025-1036, DOI 10.1016/S0016-7037(01)00831-6.

Nowack B. and Bucheli TD, 2007. Occurrence, behavior and effects of nanoparticles in the environment. Environmental Pollution: 150, 5-22, DOI 10.1016/j.envpol.2007.06.006.

Ochterski JW, 2000. Thermochemistry in gaussian. Gaussian Inc: 1-19.

Pawlyta M and Hercman H, 2016. Transmission electron microscopy (TEM) as a tool for identification of combustion products: application to black layers in speleothems. Annales Societatis Geologorum Poloniae 86: 237-248, DOI 10.14241/asgp.2016.004.

Petránek J and Pouba Z, 1951. Dating of the development of the Domica Cave, based on the study of the dark zones in the travertine formations. Sbornik Ústředního Ústavu Geologického 18: 245272. (In Czech, with English summary.)

Plimpton P, 1995. Fast Parallel Algorithms for Short-Range Molecular Dynamics. Journal of Computational Physics 117: 1-19, DOI 10.1006/jcph.1995.1039.

Poole I, Braadbaart F, Boon J.J and van Bergen PF, 2002. Stable carbon isotope changes during artificial charring of propagules. Organic Geochemistry 33: 1675-1681, DOI 10.1016/S01466380(02)00173-0.

Pósfai M and Molnár A, 2000. Aerosol particles in the troposphere: A mineralogical introduction. Environmental mineralogy 2: 197-252.

Preston CM and Schmidt MWI, 2006. Black, pyrogenic carbon: a synthesis of current knowledge and uncertainties with special con- sideration of boreal regions. Biogeosciences 3: 397-420, DOI 10.5194/bg-3-397-2006.

Qian Y, Engel MH and Macko SA, 1992. Stable isotope fractionation of biomonomers during protokerogen formation. Chemical Geology 101: 201-210, DOI 10.1016/0009-2541(92)90002-M.

Reimer PJ, Bard E, Bayliss A, Beck WJ, Blackwell PG, Bronk- Ramsey C, Buck CE, Cheng H, Edwards LR, Friedrich M, Grootes PM, Guilderson TP, Haflidason H, Hajdas I, Hatté C, Heaton TJ, Hoffmann DL, Hogg AG, Hughen KA, Kaiser FK, Kromer B, Manning SW, Niu M, Reimer RW, Richards DA, Scott EM, Southon JR, Staff RA, Turney CSM and van der Plicht J, 2013. IntCal13 and Marine13 radiocarbon age calibration curves 050,000 years cal BP. Radiocarbon 55: 1869-1887, DOI 10.2458/azu js rc.55.16947.

Rowell RM and LeVan-Green SL, 2005. Thermal Properties. In: Rowell RN, ed., Handbook of Wood Chemistry and Wood Composites. CRC Press: 128-145.

Schmidt MWI, Skjemstad JO and Jäger C, 2002. Carbon isotope geochemistry and nanomorphology of soil black carbon: black charnozemic soil in central Europe originate from ancient biomass burning. Global Biogeochemical Cycles 16: 1123, DOI 10.1029/2002GB001939.

Shafizadeh F, 1984. The chemistry of pyrolysis and combustion. In: Rowell RM, ed., The chemistry of solid wood. Advances in Chemistry Series 207: 489-529, DOI 10.1021/ba-1984-0207.ch013.

Song J, Huang W and Peng P, 2012. Stability and carbon isotope changes of soot and char materials during thermal oxidation: Implication for quantification and source appointment. Chemical Geology 330-331: 158-164, DOI 10.1016/j.chemgeo.2012.08.003.

Steelman KL, Rowe MW, Boutton TW, Southon JR, Merrell CL and Hill RD, 2002. Stable isotope and radiocarbon analyses of black deposits associated with pictographs at Little Lost River Cave, Idaho. Journal of Archaeological Sciences 29: 1189-1198, DOI 10.1006/jasc.2001.0791.

Turney CSM, Wheeler D and Chivas AR, 2006. Carbon isotope fractionation in wood during carbonization. Geochimica et Cosmochimica Acta 70: 960-964, DOI 10.1016/j.gca.2005.10.031.

Vane CH and Abbott GD, 1999. Proxies for land plant biomass: closed system pyrolysis of some methoxyphenols. Organic Geochemistry 30: 1535-1541, DOI 10.1016/S0146-6380(99)00125-4.

Watson PJ, 1966. Prehistoric miners of Salt Cave, Kentucky. Archaeology 19: 237-243.

Wickman FE, 1952. Variations in the relative abundance of the carbon isotopes in plants. Geochimica et Cosmochimica Acta 2: 243-254, DOI 10.1016/0016-7037(52)90018-5.

Zhang T, Li X, Qiao X, Zheng M, Guo L, Song W and Lin W, 2016. Initial mechanisms for an overall behavior of lignin pyrolysis through large-scale ReaxFF molecular dynamics simulations. Energy \& Fuels 30: 3140-3150, DOI 10.1021/acs.energyfuels.6b00247. 